ISSN: 2162-3104 Print/ ISSN: 2166-3750 Online Volume 6, Issue 3 (2016), pp. 722-732 (C) Journal of International Students http://jistudents.org/

\title{
Factors Influencing Chinese Students' Decisions to Study in the United States
}

\author{
Larry Austin \\ University of Phoenix, USA \\ Libi Shen \\ University of Phoenix, USA
}

\begin{abstract}
The central research question was: Why do Chinese students want to study in the United States? The participants were 20 Chinese students who studied in the U.S. Ten interview questions were used and data were processed in NVivo 10. Five major themes emerged from this study: (a) American culture benefits foreign perceptions of education in the U.S.; (b) increased personal wealth increases demands for educational freedom; (c) Chinese test performance does not indicate education quality; (d) Chinese culture clashes with students' desire for self-actualization; and (e) an education in the U.S. is considered an immigration stepping stone.
\end{abstract}

Keywords: education, cultural differences, economic factors, cultural factors, political factors

The number of Chinese students studying in the U.S. has increased drastically over the years. China ranked as the top country of the origin for U.S. bound international students for six years in a row, with 98,235 students in 2009, 127,822 students in 2010, 157,558 students in 2011, 194,029 students in 2012, 235,597 students in 2013, and 274,439 students in 2014 (Institute of International Education, 2015). The bulk of student applications have changed from a majority of graduate students to mostly undergraduate students (Chow, 2011). According to the Institute of International Education (2015), there were 886,052 international students studying in colleges and universities in the U.S. in the 2013/2014 academic year, contributing more than $\$ 27$ billion to the U.S. economy in 50 states. 
Among them, China remained the top country of origin by providing 31\% of all international students in the U.S. (Institute of International Education, 2015). However, the report from the Institute of International Education (2015) did not provide reasons why more and more Chinese come to the U.S. to study. Since research studies on the factors that influenced Chinese students' decisions to study in the U.S. are limited, it is imperative to conduct this study.

The goal of this study was to explore factors that contributed to Chinese students' decisions to study in the United States over all other options. This study could be beneficial to policy makers, university administrators, educators, and researchers. The information could provide Chinese university administrators and government officials to better understand how they might improve curriculum or policies to retain Chinese students. University administrators in the U.S. could use the information to make better decisions on students' admission policies. Educational leaders can identify potential problems, adjust learning programs, or refine the enrollment process to better serve the needs of international students.

\section{LITERATURE REVIEW}

There were three theories that provided the foundation for this study: Constructivism, Social Learning, and Confucianism. Constructivism maintains that personal experiences and social situations influence a person's perception of reality. Constructivism involves the belief that people create references for events and influences to give them a sense of meaning and order (Hein, 1991). Learning is regarded as a process that requires individuals to form new references from sensory input actively and to construct new meaning from events they experienced in the past (Hein, 1991). Albert Bandura's Social Learning Theory focuses on the actions of others as a teaching tool (Culatta, 2012). Bandura reasoned that people learned by watching the actions of others and from their observations determined which actions were safe or unsafe to repeat (Culatta, 2012). Human beings are unique in that they do not need to experience something personally to understand whether a particular thing is good or bad. Confucianism emphasizes great respect for social order and traditional family values (Lu, 2014). In Confucius' doctrine, there should be no distinction of the classes in teaching (Legge, 2004). The teachings of Confucius help cement the importance of education into the minds of the Chinese people and communicate the importance of education as a way of social advancement. 


\section{Overview of Chinese Education}

During the last century, China has witnessed many changes-the most important of these being the rise in power of the Chinese Communist Party in the 1940s. Before the establishment of the People's Republic of China, about $80 \%$ of the Chinese population was illiterate; after the establishment of the People's Republic of China in 1949, greater emphasis was placed on educational equality (China in Brief, 2000). The Chinese Cultural Revolution in the 1970s reversed education progress, and thrust the entire country into chaos. "Young people were encouraged to revolt and to attack the four olds: old ideas, old customs, old habits, and old culture" (Adams, Stivers, \& Bin, 2003, p. 70). All throughout China, educators and cultural elites were denounced and forced into re-education farms or prisons, where many died. After the death of Mao Zedong, those who promoted the Cultural Revolution-known as the gang of four-were denounced and imprisoned (Adams, Stivers, \& Bin, 2003).

Over the centuries, Chinese culture has emphasized education as a vehicle for personal advancement based on the teachings of Confucius. In ancient China, around 124 B.C., Chinese education gained importance during the reign of the Han emperor $\mathrm{Wu} \mathrm{Ti}$; the best candidates for government positions were selected using rigorous testing (i.e., national examination) instead of personal position or influence (California State Polytechnic University, n.d.). Crozier (2002) emphasized that cognitive testing was the fairest way to select the most qualified candidates for government positions. Chinese people have traditionally believed that hard work and a good education could help them gain success and a better life (Hennock, 2009).

As Sit (2013) indicated, Chinese education has evolved into a system of competitive testing to eliminate all but the best candidates from educational opportunities. During their last year of high school, Chinese students learn nothing new but focus all efforts on preparing for the highly rigorous college entrance exam called the Gaokao (Markleine, 2009). The purpose of the Gaokao is to limit access to Chinese universities, by rejecting all but the best students. Markleine (2009) mentioned that student' Gaokao scores are extremely important because they determine which university a student may be admitted. Students with higher scores may be admitted into the most prestigious universities, while those with lower scores have fewer or no options for university acceptance. Competitive testing has saturated all aspects of a Chinese student's life and has been recognized as a cause of problems with school age children.

\section{Chinese Parents' Expectations}

Although educational opportunities may not be equally available, many Chinese families believe that obtaining a good education is essential for 
better life (Yi et al., 2011). Li and Li (2010) found that schools continued to promote after-school classes to occupy the free time that children should have. Parents often resort to extreme measures to ensure that children will be accepted into key schools. In the interest of fairness, the Chinese government changed school admission policies based upon student's residency. In the geographic areas with the best schools, wealthy parents eagerly purchased property, which increased real estate prices near key schools (Li \& Li, 2010).

According to the Asian Scientist (2011) and U.S. News and World Report (2012), the majority of the highest rated universities are in the United States. Since only a limited number of Chinese students are rewarded with access to the best universities based upon the results of a single competitive test, some families pay close attention to the reported rankings of worldwide institutions. The traditional emphasis on education as a means for advancement and the reality of one-child families mean that parents have more resources available to benefit their offspring. Because educational opportunities are limited and the demand is high, the Gaokao system of testing eliminates students with less dedication and talent for university life (Markleine, 2009).

Pollock (2009) stated that the Central Government of China discourages educators from teaching subjects that may encourage political debate and strictly controls the content of curriculum available to students. From popular Western media, many Chinese students have developed the notion of the U.S. as a country where people are more relaxed and uninhibited, which is an appealing alternative to their own culture of conformity and competition for scarce resources.

\section{Chinese Economy - the Rise of Chinese Middle Class}

During the past two decades, economic development and social changes have not only brought numerous benefits and opportunities to the Chinese people, but also presented major challenges to the country (Wang \& Morgan, 2012). As Wang and Morgan (2012) reported, economic prosperity has induced many rural workers to leave agricultural jobs for better paying industrial jobs in urban areas. The new Chinese middle class is likely to seek the best opportunities available to improve their living standards and chances for prosperity. Li and Li (2010) noted that China's rapid economic development has provided increased educational opportunities for many students. "The children nowadays can no longer imagine the poverty in the previous generation when their parents still had to strive for proper meals and warm clothes, and lost many opportunities such as going to universities” ( $\mathrm{Li} \& \mathrm{Li}, 2010$, p. 213). China's economic growth has led to the creation of a middle class with an ability to freely invest in the education of an only child, which has increased demand for 
more educational resources within and outside of China. All across China, middle class families are sending children to English language schools to provide them with a better advantage later.

From 1970s to 1990s, most Chinese students attending American institutions were primarily graduate students; however, recent trends indicate an increase of Chinese undergraduate students studying in the U.S. The recent increase in undergraduate students attending American universities may be partly attributed to the increased prosperity of the new middle class in China. Chinese students are able to pay 100\% of the costs and tuition for American universities, even though these costs are twice as expensive as the costs for American students (Tang, 2014). Steinberg (2011) described that China's economic progress during the last couple of decades has created a new middle class that can afford to pay children to attend a good university abroad. Mong (2012) also claimed that Chinese undergraduate students are mostly self-funded due to the recent increase in the Chinese middle class, while foreign students in the United States spend around 21 billion U.S. dollars each year for education expenses. In a society that values education as a means of advancement, some might ask if the level of economic prosperity affects choices families make to send their children to intuitions in the United States over other international locations.

\section{American Image}

In the U.S., freedom of expression and debate may offer new paths of expression to students who were traditionally told what to do and how to think at all times. Popular media has perpetuated the concept of the American Dream and culture of freedom throughout the world. Some students may simply be curious about American culture and choose to study in the United States to experience this culture. Zhao, Zhou, and Huang (2008) reported that many Chinese see the United States as the wealthiest, technologically advanced superpower in the world. The three most common beliefs Chinese students have about the United States is that it is a land of great strength and military power; it has the best schools with access to advanced technology; and it offers the freedoms of a democratic society (Zhao, Zhou, \& Huang, 2008). Many Chinese students may want to escape the pressures of the educational system in China, which they view as mostly test-oriented while promoting the societal goals of a collectivist society rather than developing students for individual accomplishments (Zhou, Zhou, \& Huang, 2008).

Wong (2001) indicated that many students believe the exposure to American business culture and a diploma from an American university can benefit them in the Chinese job market. When comparing the differences between Chinese and American education, culture, business standing, and power, one may conclude that China is a land of scarcity and shortages but 
continual developing. America, on the other hand, may appear as a land of abundance and opportunity. Chinese students who study in the U.S. might be more desirable employees when they return to China.

Many Chinese students believe that America is a place of where they can increase creativity and reasoning skills (Tang, 2014). In China, lessons that teach independent thought and creativity are not as valued in a country that teaches adherence to strict cultural norms. Adams, Stivers, and Bin (2003) stated that Chinese students still use the same learning methods from Confucian tradition, which emphasize learning large amounts of materials through rote memorization and providing evidence of learning with strict cognitive testing. The Chinese technique of rote memorization seems to work well for teaching basic facts and concepts, but does not promote critical thinking skills. Chinese students believe that American schools are better financed equipped than universities in China. Laprete (2008) argued that even though Chinese universities can offer solid teaching in basic subjects, studying in the U.S. offers more opportunities for learning about diversity in an open learning environment. Many Chinese students believe that the teaching culture of the United States is much different from theirs (Tang, 2014).

\section{Chinese Immigration to America}

Chinese people were some of the earliest of Asian immigrants to America, initially arrived in the American West during the California Gold Rush of 1848 and again in 1852 as a greater number of Chinese immigrants arrived in America helped build the Central Pacific Railroad (Pew Research Center, 2012). The Pew Research Center (2012) reported that as the gold in the U.S. became increasingly difficult to find and railroad jobs disappeared, many Chinese were forced to live in segregated areas with menial low paying jobs. Since their arrival, Asian Americans have repeatedly endured discrimination, including laws prohibiting Asian immigrants from coming to the U.S. (Pew Research Center, 2012).

America has been an important travel destination for Chinese citizens for many years. The opportunities increased as the United States and Chinese governments negotiated visas that can be valid for ten years for business people, tourists, and students (Chappell, 2014). Increased levels of tourism and travel opportunities are viewed as important goals for both countries for increased prosperity (Chappell, 2014). The American dream has not been lost on the imaginations of the Chinese people. Although many Chinese students deeply love their country, many may desire greater freedoms than are currently available in China. As Chinese citizens gain opportunities for travel, some may desire to escape the disadvantages they experience at home in China (Browne, 2014). 


\section{Factors Influencing Chinese Students' Decisions to Study in the U.S.}

Research studies on the factors leading to Chinese students' decision to study in the United States are limited (e.g., Liao, 2012; Lu, Marondo, \& Qiu, 2009; Phang, 2013; Zhao, Zhou, \& Huang, 2008). Zhao, Zhou, and Huang (2008) reported that Chinese students seem to be interested in the American system of education not because of education quality, but because of a dislike for the Chinese education system. Lu, Marondo, and Qiu (2009) illustrated that motivation to live and work overseas, the availability of university scholarship, university ranking, and domestic website information are all factors influencing Chinese students' decisions to study in the U.S. Additionally, increased prosperity and the greater buildup of a middle class have led to increased travel and tourism opportunities for Chinese people (Liao, 2012). Phang (2013) posited that the increased demand for Chinese students attending overseas educational institutions could be partially explained by the role the Internet plays in making information more freely available. Phang (2013) explained that the Internet has generated greater business opportunities and allowed greater access to information regarding educational institutions that may have been more difficult to obtain in the past.

Global changes in recent decades have not only affected affairs inside of China, but also influenced politics and culture throughout the entire world. As China becomes increasingly open to foreign trade and influence, new opportunities have opened up for Chinese citizens. Among these new opportunities, Liao (2012) mentioned that relaxed travel restrictions on Chinese citizens have been a result of market reforms and an open door policy. Even though China has experienced high levels of economic improvement and limited political reforms resulting from greater prosperity, evidence indicated that some Chinese wish to emigrate out of the country. Terrazas and Batalova (2010) and Vandermeid (2003) claimed that more than half of Chinese immigrants to the United States were likely to have a Bachelor's Degree or higher and are usually more educated when compared to other American immigrants.

According to the International Business Times (2012), wealthy Chinese families influenced by centuries of Chinese culture are investing heavily in the education of children. Many Chinese students are seeking out educational opportunities that emphasize greater critical and creative thinking skills, which have been traditionally offered in the United States, rather than subjecting children to the old Chinese system of learning (International Business Times, 2012). Vandermeid (2003) and the International Business Times (2012) mentioned that the Chinese one child policy has influenced families to spend more on their child's education as an investment for the future. 
The topic of motivation could be addressed further on many levels and from many perspectives. Mong (2012) reported that Chinese students must deal with massive competition for Chinese university admission, which could make the possibility of attending an American university much more attractive. Marklein (2009) found that American universities have a well-established tradition of working with Chinese students to help them meet their educational goals, as Chinese universities are unable to keep up with Chinese students' demand for a university education.

With a population of about 1.36 billion people in China, Chinese job seekers may face strong market competition. Hennock (2009) predicted that the economy in China is slowing down and college graduates are experiencing more difficulties in finding jobs. Hennock (2009) also mentioned that increasing unemployment for university graduates is very worrisome for government leaders in Beijing. Chinese students compete against one another from the time they begin elementary school until the time they graduate from college.

\section{RESEARCH METHOD}

\section{Research Design}

This study employed a qualitative method with an intrinsic case study design. A case study provides information from an individual perspective and sheds light on a larger picture that outsiders can understand (Christensen, Johnson, \& Turner, 2011). Intrinsic case study design focuses on performing an investigation of a specific individual or group as a way to better understand events, actions, or thought processes of that person or group. As Hancock, Dawson, and Algozzine (2011) suggested, the goal of the design is to understand the theory of why something happens rather than the facts of what happened. Many issues that influence the decisions of Chinese students might be dependent upon multiple combinations of factors. This case study attempted to understand the specific factors that underlie Chinese students' decision to study in the United States over all other possible alternatives. The research design is appropriate because an intrinsic approach assists an investigation of the multiple, unique factors that influenced the perspectives of the participants. As Gilgun (2011) noted, an intrinsic approach to case studies helps emphasize the unique and personal perspectives of the study participants. The strength of a case study with multiple participants also helps researchers focus on details of phenomenon that are shared by more than one subject; the resulting data could provide more general information regarding circumstances that have been shared by the subjects (Christensen, Johnson, \& Turner, 2011). 


\section{Participants}

The study participants were 20 Chinese students from the People's Republic of China who lived within a 50-mile radius of College Park, Maryland at the time that the research data were gathered. The participants for this case study involved Chinese students over 18 years old who have attended, or are currently attending educational institutions in the United States, and who speak English well. The researcher recruited participants from restaurants, shopping centers, malls, libraries, fitness centers, and churches in the communities near College Park, Maryland.

\section{Procedure}

After obtained IRB approval on July 23, 2014, twenty Chinese students who resided at or near College Park, Maryland were recruited to participate in this study. The participants submitted informed consent forms before the interview and all interviews were digitally audio recorded with the participants' permission. After the interviews, the researcher contacted the participants by telephone to verify their responses. The audio data were converted to written transcripts and NVivo $10 \AA$ software was used to assist with data analysis.

The written documents and the audio data from each interview session were imported into the NVivo $10 \AA$ software. The audio data were converted to written transcripts during data analysis. After editing to improve clarity, the written documents were coded and categorized into NVivo 10® nodes. Each node was developed from a category from common participant response topics. For example, if a participant expressed a desire to stay in the U.S. after graduation, the participant's answers were assigned to a node titled "Stay in the U.S.A." After coding all of the documents, the complete list of nodes were examined to determine the most popular response categories. In addition to creating nodes for response categorization, NVivo $10 \AA$ also generated word counts from all of the documents; this feature helped identify popular participant responses and also helped identify potential node categories.

\section{RESULTS}

Twelve emergent themes were identified through NVivo 10 process. Those themes included: the perception of U.S. educational institutions as the best in the world, the U.S. as a study destination to improve English language skills in a native setting, the U.S. as a destination for travel and adventure, the high cost of an education in the U.S., the challenges of adapting to American culture, the importance of a social support networks - friends and 
family, an extremely limited level of political expression, the importance of university rankings, the importance of parental support, the competitive advantage of a U.S. education, the hope that a U.S. education can provide an opportunity for work in the U.S. after graduation, and the desire for a permanent life in the United States. Five major themes were developed as follows by combining the emergent themes: (a) American culture benefits perceptions of U.S. educational intuitions; (b) Increased personal wealth increases demand for freedom; (c) Chinese test performance does not predict education quality; (d) Chinese cultural obedience clashes with students' desire for self-actualization; and (e) A U.S. education is considered an immigration stepping-stone. Table 1 presented the themes with examples.

\section{Theme 1: American Culture Benefits Perceptions of U.S. Education}

The United States of America and the cultural ideals represented by it provide an attractive study destination as many students seek an escape from the restrictions they faced from multiple sources. Respondents P01, $\mathrm{P} 05, \mathrm{P} 07, \mathrm{P} 10, \mathrm{P} 11, \mathrm{P} 12, \mathrm{P} 13, \mathrm{P} 14, \mathrm{P} 17$, and $\mathrm{P} 18$ cited their desire to travel-an activity that is still restricted in China. Respondents P01 and P20 expressed a desire to learn about the people who come from the many different world cultures that live in the United States. The opportunity to study English in the U.S. was considered important by respondents P05, P07, P08, P11, P19, and P20, since English is the most widely spoken language in the world and used in business. Some respondents mentioned that an American education would make them more competitive in the job market at home. Respondent P02 said, "If you have a degree from the U.S. it's easier to find a job in China." P06 believed that studying in the U.S. would benefit her future development. P06 further described that with an overseas educational background, her advantage in academic profession, global vision and language skills will make her very competitive. Many of the respondents also indicated that they would like to stay in the United States after graduation to live and work. P15 noted that he wants to find a job in the U.S. with long-term development prospects after graduation. Respondent P11 also said that she wants to find a job and tries to stay in the U.S. after graduation. A few of the respondents also indicated that they wanted to become citizens of the United States. Respondent P15 explained that she is a permanent resident of the U.S. now and may go back to visit China after she becomes a U.S. citizen.

\section{Theme 2: Increased Personal Wealth Increases Demand for Freedom}

Nearly all of the study respondents indicated their families were wealthy enough to easily afford sending them to study abroad in the U.S. Respondent P15 emphasized the amount of funding available to her by 
saying, "Economic reasons never affected my decision to study where I wanted because I was born into a family that can afford the tuition for the United States.”

\section{Table 1: Major Themes and Examples}

Major Themes

Examples

American culture benefits perceptions of U.S. education.
- $\quad$ People in the U.S.A. have more freedom to travel and experience other cultures.

- $\quad$ An education in the U.S.A. can offer a native approach to mastering English language skills.

- The U.S.A. offers greater academic and personal freedoms.

Increased personal wealth increases demands for freedom.

- The accumulation of wealth has enabled students to afford tuition at top rated universities.

- Greater wealth has increased the demand and ability for travel.

- Wealthy students seek to escape China's competitive education culture.

Chinese test performance does not • Curriculum in China is designed to suit predict education quality. the requirements of the Central Government.

- $\quad$ Classes are taught verbatim out of books.

- Chinese teachers are regarded as less creative than American teachers are.

Chinese cultural obedience clashes - Chinese tradition emphasizes a duty to with students' desire for self- care for elderly family members. actualization.

- Cultural norms encourage obedience and conformity.

- $\quad$ Children are pressured to excel in a highly competitive educational culture.

A U.S. education is considered an immigration stepping-stone.
- A U.S. education prepares Chinese students to compete in the U.S. job market.

- Most students report their desire to stay in the U.S. if an opportunity arises.

Respondent P12 noted that males have more financial responsibilities in Chinese culture and need to buy a house before they can marry. However, Respondent P12 said, “Since I'm a girl, my parents did not 
need to save money for a house. They could use their money to send me to a foreign university, and that's why I chose to study in the United States." Therefore, girls may benefit more from family wealth to study in the USA than boys may. Respondent P10 noted that personal wealth has created a kind of democracy in China as students now vote with their feet, and leave the country. Many Chinese families can now give their children more education freedom. Chinese students often speak of personal freedom rather than political freedom. Most students do not exhibit a political opinion. Respondent P10 thought that politics is too good for her to think about because she does not know about things like that.

\section{Theme 3: Chinese Test Performance Does Not Predict Education Quality}

Some respondents expressed discontent with the education they received in China and how limited access to educational resources, or poor test scores, might affect their future. Respondent P10 described that many teachers in China only read out of textbooks and do not have much experience. Respondent P14 complained about the amount of preparation necessary to prepare for the Gaokao test and the last year and half of high school was a total waste of time. P14 also complained that schools were often judged as good or bad, and "If you fail one exam, it may kill your future, because you just cannot go to a good school for the next four years, and maybe then you can't find a job, because you failed going to that good school." A few of the respondents complained about the Chinese curriculum that was available to students. As respondent P20 remarked, "One of the drawbacks of studying in China is that open discussion and critical thinking is discouraged in some cases." Respondent P10 also indicated that an American education is better than Chinese education because modern education is more developed in America, and sometimes Chinese schools copy the American style of learning.

\section{Theme 4: Chinese Cultural Obedience Clashes with Students' Desire for Self-actualization}

Chinese culture emphasizes caring for aging parents. For some students, family and cultural obligations may be stronger than their own personal desires. For others, Chinese cultural traditions conflict with their personal goals. Respondent P04 commented that Chinese parents usually insist their children to study the things they think are best. Later, their children must work in the occupation their parents want instead of what they want. Respondent P05 explained that she is very much aware of and like popular American culture. She believed that American culture influences the rest of the world; When Chinese students are exposed to American culture, it influences them to travel to the United States. Many of the study 
participants expressed their desire for independence while in the U.S. and briefly escape the influence of their parents. Respondent P09 said, "The culture difference was one of the things that I mostly wanted to experience in U.S.; it played positive role in my decision to come here.” Respondent P10 underscored the importance of education as an investment with, "because there are not many avenues for investment in China; many parents think it is wise to invest in their children as a way to ensure a kind of security as they grow older."

\section{Theme 5: A U.S. Education is considered an Immigration Stepping- stone}

Out of the twenty participants in the study, seventeen indicated that they would like to stay and work in the U.S. Respondents P03, P06, P10, P13, and P14 mentioned their desire to stay and work only a short while to gain professional experience before returning to China. However, respondents P02, P04, P05, P08, P09, P11, P12, P15, P16, P17, P18, and P20 registered their desire for long-term residency in the U.S. Additionally, respondents $\mathrm{P} 05, \mathrm{P} 11$, and $\mathrm{P} 15$ expressed their desire to live permanently in the U.S. Although many of the respondents expressed that they would eventually return to China, most indicated their desire to establish a professional career in the U.S. over a longer period of time. It would then seem logical that when students can stay in the U.S. for many years, they might be increasingly reluctant to return to China after building a career, a network of friends, and possibly family in the U.S.

\section{DISCUSSION AND CONCLUSIONS}

The findings indicated that Chinese students' perception of U.S. educational institutions, the support from the family, the rankings in the U.S. universities, the competitive advantage of a U.S. education, the opportunity to work in the U.S., and the desire for a permanent life in the United States all contributed to their decisions to study in the U.S. Many participants perceived the U.S. as a place of freedom, opportunity, and wealth. The participants indicated that they got their information from movies and television shows, which portrayed Americans very wealthy and unfettered by cultural tradition. As they had an intense desire for success, wealth, and freedom, the participants' responses provided a strong indication of the level of influence American popular culture had on their decisions to study in the U.S.

Additionally, the majority of the participants reported that their families could easily afford sending them to the United States to study. As Tang (2014) noted, when personal wealth has increased for and secured the 
development of a Chinese middle class, many families now have the means to send their children abroad to attend better schools. Chinese parents often consider the United States as the best choice for students who desire access to the most modern technology and the highest rated universities. Melcher (2010) noted that there is strong demand in China to prepare students to study abroad, with some unscrupulous companies helping students cheat to gain access to top rated universities in the U.S.

Nearly all of the interview participants complained about their last year of high schools in China focusing solely on preparing for the college entrance exams. Some respondents expressed discontent with the education they received in China and how limited access to educational resources or poor test scores in college entrance examination might affect their future. This is consistent with Tang's (2014) findings that an increasing number of Chinese students are coming to the United States during high school to avoid taking the Chinese college preparation exams and to become integrated into the American education much sooner to increase their chances of gaining admittance to a prestigious U.S. university.

The Chinese Central Government strictly regulates school curriculum and focuses mostly on subjects that do not require creative thought. Chinese students often complained that many Chinese university professors merely stand in front of the class and read from government approved textbooks. All of the respondents stated that they believed the institutions in the U.S. offered better opportunities to acquire critical thinking and problems solving skills.

Chinese culture emphasizes caring for aging parents. For some students, family and cultural obligations may be stronger than their own personal desires; for others, Chinese cultural traditions conflict with their personal goals. As Chinese students are increasingly exposed to western freedom, trends, and culture, they may develop a heighten desire to escape the pressures for obedience and conformity they face at home. The majority of the interviewees insisted that they wanted to stay in the U.S. to live and work to maximize their chances for life success, and perhaps visit China later when they have greater resources to finance the care for their parents. Tang (2014) remarked that Chinese students want the things that nearly everyone wants; they are no different from people all over the world. Ninety percent of the participants for this study reported a basic desire to stay in the United States to work for varying lengths of time. They admitted that they want to stay in the United States as long as they could find employment or if a good career opportunity is presented. The participants who wanted to stay a short time in the U.S. after graduation expressed a strong sense of duty toward their families and Chinese cultural tradition. Four participants said they wished to permanently live and work in the U.S. Although the evidence suggested that Chinese students might use their 
university experience as a stepping-stone for a prolonged stay in the U.S., they also face intense pressure from family and cultural sources to return to China. Many issues surrounding Chinese immigration to the U.S. are highly complex and continually changing and would need further study to reach concrete conclusion.

\section{LIMITATIONS}

There were numerous limitations for the study. First, the collected data were obtained after the interviewed participants lived and studied in the United States for some time; prolonged exposure to American culture may have influenced their attitudes slightly. Had the data been collected in different time or place, the results might be different. Second, the collected data were limited to students' location; it is unknown if different study locations would have changed the data. Third, the number of participants was limited in a case study so it cannot be generalized to a large population. Perhaps a different research method and design might yield different results. Therefore, further studies are needed.

\section{REFERENCES}

Adams, J. S., Stivers, B. P., \& Bin, L. (2003). Education for market competition: Perceptions of Chinese and U.S. undergraduates. Journal of Teaching in International Business, 15(2), 65 doi: 10.1300/J066v15n02_05

Asian Scientist. (2011). Shanghai Jiaotong releases 2011 academic rankings: U.S. colleges dominate. Retrieved from http://www.asianscientist.com/academia/shanghai-jiaotong-universityacademic- ranking-of-world-universities-2011-arwu/

Browne, A. (2014, August 15). The great Chinese exodus. The Wall Street Journal. Retrieved from http://online.wsj.com/articles/the-great-chinese-exodus1408120906

California State Polytechnic University. (n.d.). Confucian and the Chinese scholastic system. Confucian Education. Retrieved from http://www.csupomona.edu/ plin/ls201/confucian2.html

Chappell, B. (2014, November 10). In China, Obama touts visa deal, progress on free-trade pact. Retrieved from http://www.scpr.org/news/2014/11/10/47966/in-china-obama-touts-visadeal-progress-on-free-tr/

China in Brief. (2000). Education. China in Brief. Retrieved from http://www.china.org.cn/e-china/education/reform.htm

Chow, P. (2011). What international students think about U.S. higher education: Attitudes and perceptions of prospective students in Africa, Asia, Europe and Latin America (Rep.)? Retrieved from Institute of International 
Education website: http://www.iie.org/ /media/Files/Corporate/OpenDoors/Special-Reports/IIE_Student_Attitudinal_Survey_Report.ashx

Christensen, L. B., Johnson, B., \& Turner, L. A. (2011). Research methods, design, and analysis (11th ed.). Boston: Allyn \& Bacon.

Creswell, J. W. (2009). Research design: Qualitative, quantitative, and mixed methods approaches (3rd ed.) [Kindle]. Thousand Oaks, CA: Sage Publications.

Crozier, J. (2002). A unique experiment. China in Focus Magazine, 12. Retrieved from http://www.sacu.org/examinations.html

Culatta, R. (2012). Constructivist theory: Jerome Bruner. Instructional Design. Retrieved from http://www.instructionaldesign.org/theories/

Gilgun, J. F. (2011). Theory and case study research [IBooks]. Retrieved from https://itun.es/us/RFpIA.l.

Hancock, D. R., \& Algozzine, R. (2011). Doing case study research: A practical guide for beginning researchers (2nd ed.) [Kindle Edition]. New York: Teachers College Press. Columbia University.

Hein, G. E. (1991). Constructivist learning theory. Institute for Inquiry. Retrieved from http://www.exploratorium.edu/IFI/resources/constructivistlearning.html

Hennock, M. (2009). To save the Chinese dream. Newsweek, 153. Retrieved from http://search.proquest.com/docview/214019486? accountid=35812

Institute of International Education. (2015). Open doors 2014: International students in the United States and study abroad by American students are at all-time high. Retrieved from http://www.iie.org/Who-We-Are/News-andEvents/Press-Center/Press-Releases/2014/2014-11-17-Open-Doors-Data

International Business Times. (2012). 90\% of China's super-rich want to send children abroad. International Business Times. Retrieved from http://www.ibtimes.com/90-china's-super-rich-want-send-children-abroad434838

Laprete, J. (2008). Chinese students pursuing U.S. education. MSNBC. Retrieved from http://www.msnbc.msn.com/id/27756029/ns/us_newseducation/t/chinese-students-pursuing-us-education/\#.T-Vui1IpDmc

Legge, J. (2004). The Chinese classics - volume 1: Confucian analects. [iBooks]. Retrieved from https://itun.es/us/II8Kv.l

Li, W., \& Li, Y. (2010). An analysis on social and cultural background of the resistance for China's education reform and academic pressure. International Education Studies, 3(3), 211-215.

Liao, D. (2012). Travel motivations of Chinese students in the United States: A case study of Chinese students in Kent State University. (Electronic Thesis or Dissertation). Retrieved from https://etd.ohiolink.edu/

Lu, Marondo, \& Qiu (2009). Factors influencing the choice of overseas study by undergraduate and post graduate Chinese students. Retrieved from http://www.duplication.net.au/ANZMAC09/papers/ANZMAC2009740pdf

Lu, R. (2014). Does studying Confucius make you smarter, or just more obedient? Retrieved from http://www.thestar.com/news/world/2014/01/25/does_studying_confucius_ make_you_smarter_or_just_more_obedient.html 
Marklein, M. B. (2009). Chinese college students flocking to U.S. campuses. U.S.A. Today. Retrieved from http://Appendix.U.S.A.today.com/news/education/2009-12-081Achinesestudents08_CV_N.htm

McCann, P. (2006). Principals' understandings of aspects of the law impacting on the administration of Catholic schools: Some implications for leadership (Unpublished master's thesis). Australian Catholic University. Retrieved from http://dlibrary.acu.edu.au/digitaltheses/public/adtacuvp129.17052007/01front.pdf

Melcher, T. (2010). WIEC2011_Fraud-in-China.pdf (Working paper No. 4). Retrieved from http://www.washcouncil.org/documents/pdf/WIEC2011_Fraud-inChina.pdf

Mong, A. (2012). Chinese applications to U.S. schools skyrocket. Behind the Wall. Retrieved from http://behindthewall.msnbc.msn.com/_news/2012/01/11/9679479- chineseapplications-to-us-schools-skyrocket?lite

Pew Research Center. (2012). The rise of Asian Americans. Retrieved from http://www.pewsocialtrends.org/2012/06/19/the-rise-of-asianamericans/?src=global-footer

Phang, S. L. (2013). Factors influencing international student s' study destination decision abroad (Master's thesis), Gothenburg, Sweden: University of Gothenburg. Retrieved from https://gupea.ub.gu.se/bitstream/2077/32136/1/gupea_2077_32136_1.pdf

Pollock, R. (2009). Chinese teaching needs more critical and creative thinking. The China Post. Retrieved from http://www.chinapost.com.tw/commentary/losangeles-times/2009/05/08/207374/Chinese-teaching.htm

Sit, H. H. W. (2013). Characteristics of Chinese students' learning styles. International Proceedings of Economics Development and Research, 62, 36-39. Retrieved from http://search.proquest.com.contentproxy.phoenix.edu/docview/152227769 9 ? accountid $=458$

Steinberg, J. (2011). From China, more students pursue the Great American Dream. NDTV.com. Retrieved from http://Appendix.ndtv.com/article/world/fromchina-more-students-pursue-the-great-american-dream-85116

Tang, D. (2014, November 3). Chinese seek freedom, edge at U.S. high schools. The Seattle Times. Retrieved from http://seattletimes.com/html/nationworld/2024313609_chinesehighschoolx ml.html

Terrazas, A. M., \& Batalova, J. (2010). Chinese immigrants in the United States. The Migration Information Source. Retrieved from http://www.migrationinformation.org/usfocus/display.cfm?ID=781

U.S. News and World Report. (2012). World's best universities: Top 400. U.S. News \& World Report. Retrieved from http://www.usnews.com/education/worlds-best-universities-rankings/top400-universities-in-the-world

Vandermeid, J. S. (2003). Welcome to frontiers. Frontiers Journal, 9(4), 71-110. Retrieved from http://frontiersjournal.org/wp- 
content/uploads/2015/09/VANDERMEID-FrontiersIX-

AsianAmericans.pdf

Wang, N., \& Morgan, W. J. (2012). The harmonious society, social capital and lifelong learning in China: Emerging policies and practice. International Journal of Continuing Education and Lifelong Learning, 4(2), 1-15. Retrieved from

http://www.nottingham.ac.uk/education/documents/research/unesco/harmo nious-societychina.pdf

Wong, E. (2001, February). The Chinese at work: Collectivism or individualism?

Retrieved

http://www.library.ln.edu.hk/eresources/etext/hkibs/hkws_0040.pdf

Yi, H., Zhang, L., Lou, R., Shi, Y., Mo, D., Chen, X., Brinton, C., Rozelle, C.

(2011). Dropping out: Why are students leaving junior high in China's poor rural areas? International Journal of Education Development.

Retrieved from

http://reap.stanford.edu/publications/dropping_out_why_are_students_leav ing_junior_high_in_chinas_poor_rural_areas/

Zhao, Y., Zhou, X., \& Huang, L. (2008). Chinese students' knowledge and thinking about America and China. Social Studies, 99(1), 13-22.

LARRY AUSTIN, EdD, is an education consultant and curriculum designer. Dr. Austin's research interests include educational leadership, instructional technology, and cultural awareness.

Email: larryaustin@email.phoenix.edu

LIBI SHEN, PhD, is a faculty at University of Phoenix. Dr. Shen's research interests include curriculum design, instructional methods, instructional technology, and K-12 education. Email: drlibishen@email.phoenix.edu

Manuscript submitted: 10/16/2015

Manuscript revision submitted: 1/13/2016 Manuscript revised and accepted. 1/18/2016 